\title{
Insects associated with tropical foliage produced in the coffee growing region of Colombia
}

\author{
Luis F. Aristizábal ${ }^{1}$, Leidy V. Cardona², Efrain R. Henao², Misael Salgado² \& Steven P. Arthurs ${ }^{1}$
}

\begin{abstract}
'University of Florida/IFAS, Mid-Florida Research and Education Center, Apopka, FL 32703, USA. larist@ufl.edu, spa@ufl.edu
${ }^{2}$ University of Caldas, Agricultural Science Faculty, Box 275, Manizales, Caldas, Colombia. leidy.cardona@cafedecolombia.com, erhenao@unal.edu.co,misael.salgado@ucaldas.edu.co
\end{abstract}

\begin{abstract}
Insects associated with tropical foliage produced in the coffee growing region of Colombia. We conducted a survey of insects and pest management practices on 34 farms growing ornamental tropical foliage plants in the central coffee region of Colombia over two years. Tropical foliage provided habitat for a diverse range of insects. In total, phytophagous or detritivorous insects from six orders, 40 families and 62 genera were collected. The most common were Hemiptera (29 genera from 16 families), followed by Coleoptera (17 genera from 4 families), Diptera ( 5 genera from 5 families), Lepidoptera ( 5 genera from 4 families), Hymenoptera ( 3 genera from 2 families) and Orthoptera (2 genera from 2 families). The most common phytophagous species were leaf cutting ants (Atta and Acromyrmex spp.), leaf beetles (Chrysomelidae), leafhoppers (Cicadellidae), stinkbugs (Pentatomidae), squash bugs (Coreidae), tree hoppers (Membracidae) and plant hoppers (Fulgoridae). Beneficial insects identified from tropical foliage included predators and parasitoids amongst 5 orders, 12 families and 22 genera. The most abundant were predators among the Coccinellidae, Chrysopidae, Reduviidae, Lycidae and Formicidae but only low numbers of parasitoids (Ichneumonidae, Braconidae and Tachinidae) were collected. A pest management questionnaire given to growers revealed a preponderance of reliance on broad spectrum insecticides with a smaller number of growers (approximately one third) also using some biological control methods. Our survey contributes basic information regarding diversity of Neotropical insects associated with ornamental foliage plants.
\end{abstract}

KEYWORDS. Insect diversity; insecticides; integrated pest management; questionnaire.

Due to the international demand for exotic flowers, the area devoted to growing ornamental tropical foliage in Colombia has increased in recent years, especially in the central coffee 'Eje Cafetero' region (Diaz 2006). The ICA (2009) reported 236 farms growing foliage plants on 617 ha in 'Eje Cafetero'. ASOCOLFLORES (2008) reported eleven species of foliage plants, including Dracaena, Anthericum and Cordyline spp. (Asparagales, Asparagaceae) as well as various palms (Arecales, Arecaceae) grown in this region for export as foliage, bouquets and other floral decorations.

Tropical foliage plants are subject to attack from various insect pests in their native and introduced range. Pests remain a significant risk factor due to the quarantine requirements of importers (ASOCOLFLORES 2008). However a problem is that to date, few studies have reported pest or beneficial insects associated with tropical foliage grown in Colombia. Therefore, we conducted (1) a regional field-based survey of entomofauna and (2) a questionnaire to determine existing pest management practices of tropical foliage farmers in this region. The objectives were to provide information that will be useful in the development of appropriate pest management information for this industry. Heliconia spp. are also widely grown in this region, but were not assessed in the present study.

\section{MATERIAL AND METHODS}

Study location. This study was conducted on 34 small farms producing tropical foliage located in 'Eje Cafetero' region, located in the central western part of Colombia en-

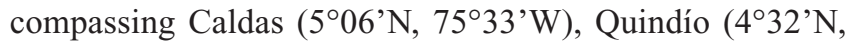
$\left.75^{\circ} 42^{\prime} \mathrm{W}\right)$, and Risaralda ( $\left.4^{\circ} 49^{\prime} \mathrm{N}, 75^{\circ} 42^{\prime} \mathrm{W}\right)$ Departments. Farms ranged in size from 1 to 26 ha with average size of 6.3 $\pm 1.1 \mathrm{ha}$. The area devoted to growing tropical foliage ranged from 0.5 to 3.6 ha with average size of $1.5 \pm 0.2$ ha. The remaining areas had agricultural crops, including coffee, Coffea arabica L., banana, Musa acuminata Colla, passion fruit, Passiflora edulis Sims, tomato, Solanum lycopersicum L., maize, Zea mays L., grass, Pennisetum clandestinum Hochst, avocado, Persea americana Mill, and Citrus L. The farms were located in 10 municipalities ranging from 930 and 1,800 m.a.s.l. with average temperatures from 18 to $25^{\circ} \mathrm{C}$, relative humidity from 70 to $85 \%$, and annual precipitation between 180 and $220 \mathrm{~cm}$. Both March to May and September to November are the typical rainy seasons in the region.

Farmer survey. Owners or managers of the farms were given a simple questionnaire about the pest management practices used on their farms. Information was obtained regarding production practices, including crops currently grown. Respondents were also asked about their experiences with insect pests, use of insecticides, biological control agents, and other pest management practices.

Insect survey. The diversity of the insect fauna associated with different foliage plants was documented. Two surveys were conducted on each farm between August and November 2006 and August and December 2007, respectively. Both insect surveys were conducted starting at the end 
of the dry season and continuing throughout the wet seasons of those years. Plants for sampling were selected along a zigzag transect which alternated every 50 meters at perpendicular directions and traversed at least $30 \%$ of the plantation area for each foliage species. For each foliage species grown, a minimum of 5 plants were sampled per ha with numbers increased proportional to the plantation area. All insects (both adults and immature stages) found during a 5 minute inspection were collected using an entomological net and placed in vials containing $70 \%$ alcohol. Specimens were identified to family, genus and, where possible, species levels at the University of Caldas using taxonomic keys and illustrated guides of Andrade et al. (1996), Fernández \& Sharkey (2006), Fernández et al. (2004), González et al.(2005), Lawrence (1991), Morales (1988), Morales \& Medina (2009) Wolff (2006) and Zumbado (1999). Voucher specimens were stored at the Entomology Laboratory of the University of Caldas.

\section{RESULTS AND DISCUSSION}

Foliage plants. In total, 11 genera and 17 species of foliage plants were produced on the 34 farms; Anthericum 'lily grass', Cordyline sp (3 species), Dracaena sp. (5 species), Eucalyptus, Ludovia 'palma canoa', Phormium 'flax', Pandanus, Pittosporum, Viburnum, Pinus 'Pino Venezuela' and Ruscus (Table I). Most farmers tended to specialize; according to our survey, each farm grew between 1 and 4 different genus of foliage, with an average of $1.9 \pm 0.2$ different genus produced. The commonest were Cordyline (grown on $38 \%$ of farms), followed by Dracaena (35\%), Anthericum (32\%), Pittosporum (21\%) and Phormium (18\%). Planting density ranged from 2,500 to 12,500 plants per hectare with harvesting generally starting from 1 to 3 years, depending on the species.

Table I. Tropical foliage plants grown on 34 farms farms in Caldas, Quindío and Risaralda Departments, Colombia.

\begin{tabular}{|c|c|c|}
\hline Order & Family & Genus (species) \\
\hline Apiales & Pittosporaceae & Pittosporum tobira (Thunb.) W.T. Aiton \\
\hline \multirow[t]{5}{*}{ Asparagales } & Asparagaceae & Anthericum saundersiae Baker \\
\hline & & $\begin{array}{l}\text { Cordyline cannifolia } \mathrm{R} \text {. Br., C. fruticosa (L.) } \\
\text { A. Chev, C. manners-suttoniae F. Muell. }\end{array}$ \\
\hline & & $\begin{array}{l}\text { Dracaena fragrans (L.) Ker Gawl., D. } \\
\text { aletriformis (Haw.) Bos, D. reflexa var. } \\
\text { augustifolia, D. sanderiana Sander ex Mast., } \\
\text { D. deremensis var. }\end{array}$ \\
\hline & & Ruscus hypoglossum $\mathrm{L}$. \\
\hline & Xanthorrhoeaceae & Phormium tenax J.R. Forst. \& G. Forst. \\
\hline Dipsacales & Adoxaceae & Viburnum macrocephalum Fort. \\
\hline Myrtales & Myrtaceae & Eucalyptus pulverulenta Sims, cv. Baby Blue \\
\hline \multirow[t]{2}{*}{ Pandanales } & Pandanaceae & Pandanus amaryllifolius Roxb. \\
\hline & Cyclanthaceae & Ludovia lancifolia Brongn. \\
\hline Pinales & Pinaceae & Pinus L. \\
\hline
\end{tabular}

Pest management. Most tropical foliage producers (91\%, $\mathrm{n}=31$ ) relied on broad spectrum insecticides. Farmers generally used at least two of the following materials, chlorpyrifos, acephate and carbofuran, which were often tank mixed with fungicides and herbicides. Our questionnaire also found that while a majority $(68 \%, \mathrm{n}=23)$ of respondents reported that they were familiar with the concept of using biological control agents, less than half $(32 \%, n=11)$ reported having used them on their farms. Biological control methods reported from these farmers were applications of entomopathogenic fungi of the genus Isaria (= Paecilomyces) fumosorosea Wize and Beauveria bassiana (Balsamo) Vuillemin and Metarhizium anisopliae (Metchnikoff) Sorokin, releases of predatory lacewings and parasitoid wasps of the genus Trichogramma spp. and repellent plant extracts based on garlic and pepper. A single farm relied exclusively on biological control methods. The reasons provided by farmers for not using biological control agents included perceived lack of effectiveness and lack of awareness regarding their availability. Thus, it appears that there is a need for research and education efforts in non-chemical control practices.

Phytophagous and detritivorous insects. Tropical foliage provided habitats for a diverse range of insects. In total, plant or detritus feeding insects from six orders, 33 families and 62 genera were identified from plantations (Table II). The most common order was Hemiptera (29 genera from 16 families), followed by Coleoptera (17 genera from 4 families), Diptera ( 5 genera from 5 families), Lepidoptera ( 5 genera from 4 families), Hymenoptera ( 3 genera from 2 families) and Orthoptera ( 2 genera from 2 families). Additional unidentified specimens from other families were also collected (Fig. 1).

The most frequently encountered hemipteran pests were leafhoppers (Cicadellidae), followed by squash bugs (Coreidae), stink bugs (Pentatomidae), treehoppers (Membracidae), soft scales (Coccidae), and other plant bugs (Fulgoridae and Miridae) (Fig. 1). Hemiptera are sap sucking insects which do not remove foliage directly, but infestations may cause economic damage to plants. For example, leafhopper feeding can reduce plant vigor, damage aesthetics through foliage deformation, and transmit plant diseases. Adult and immature Draeculacephala soluta Gibson, 1919, Emposca kraemeri Ross \& Moore, 1957, and Erythroneura spp. were collected from Anthericum, Cordyline, Dracaena, Phormium, Pandanus, Pittosporum and Viburnum. Leafhoppers are significant agricultural pests in Colombia. Heavy yield losses have been reported for E. kraemeri infestations on common beans Phaseolus sp. (Kornegay \& Cardona 1990). Adult treehoppers of the genera Archasia and Stictocephala were observed feeding on stems and branches of Cordyline, Dracena, Ludovia, Phormium, Pittosporum, Viburnum and Eucalyptus. Adult Stictocephala spp., which are known pests of trees including willows (Salix) and apple (Malus) elsewhere (Ewierczewski \& Stroiñski 2011), were noted to favor Viburnum in this region and were also found in association with ants. Ants were also observed protecting populations of soft scales Ceroplastes and Saissetia spp. collected from Cordyline, Phormium, Pandanus and Pittosporum. Large colonies of aphids (Myzus persicae Sulzer, 1776) were found on Pittosporum and Viburnum. Various other hemipteran species were found in low numbers. 

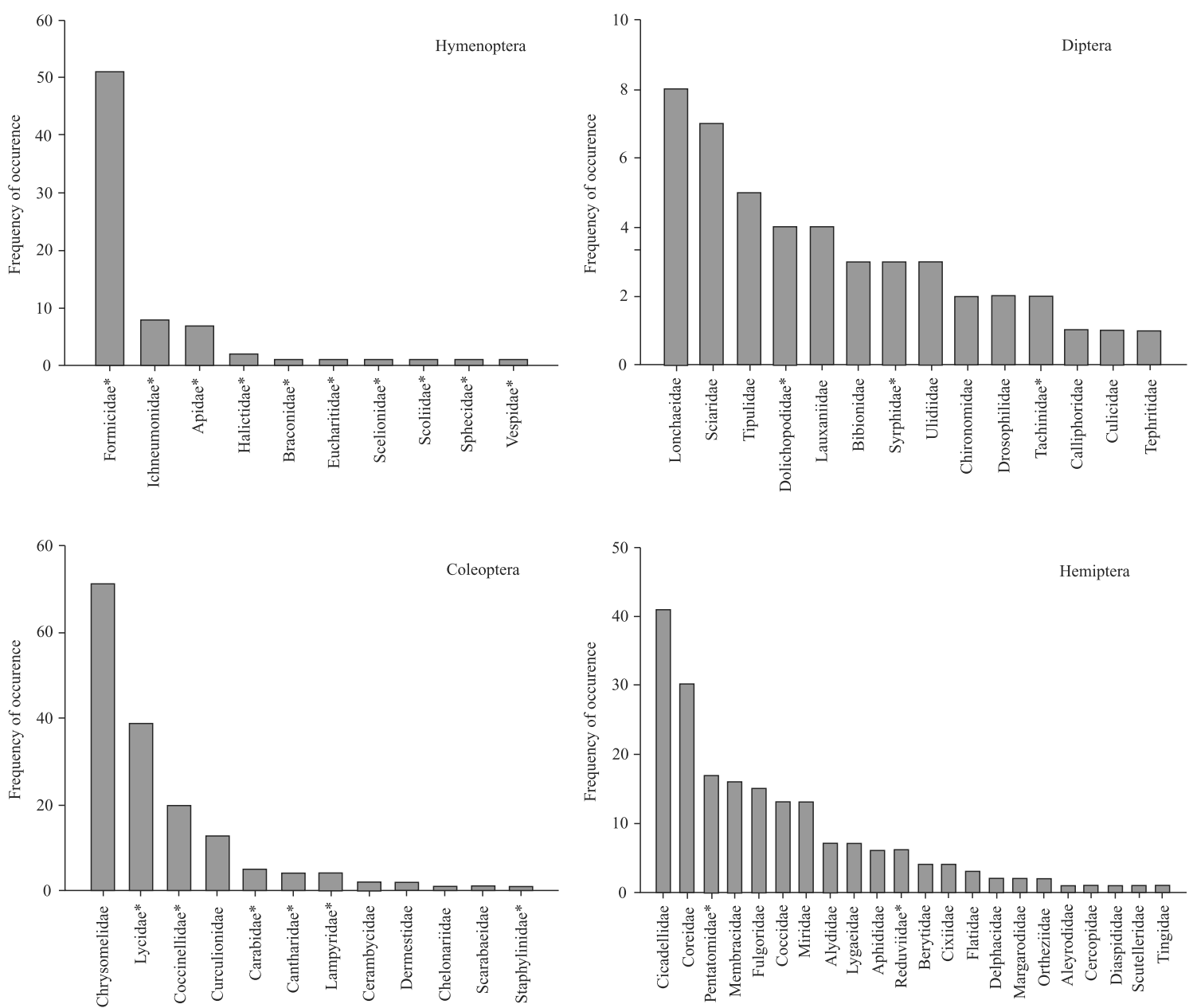

Fig. 1. Occurrence of four most common insect orders collected among 34 farms growing tropical foliage in Caldas, Quindío and Risaralda Departments, Colombia. Data are number of plants from which insects were collected. Asterisks denote families including beneficial species.

Leaf feeding beetles (Chrysomelidae) were the most common herbivores on young foliage, with specimens identified from eight genera (Table II). Leaf beetles included the tortoise beetle Agroiconota (Cassidinae) found on Pandanus and skeletonizing flea beetles Cerotoma, Diabrotica, Epitrix, Omophoita, Systena (Galerucinae) more found on Anthericum, Cordyline, Dracaena, and Pittosporum. Leaf beetles have chewing mouthparts and typically remove developing foliage between secondary leaf veins whilst immature stages of many flea beetles also attack the root system of plants (although we did not assess root damage). Adults of Epitrix and Cerotoma, previously known as pests of solanaceous and leguminous crops (Meyer et al. 1993; Kabaluk \& Vernon 2000), were amongst the most common species found in our surveys. The host ranges for Neotropical Cassidinae are poorly defined, although likely to be much greater than previously reported (Descampe et al. 2008). It would be informative to conduct additional surveys to determine the species diversity and host range of leaf beetles in this region. Leaf beetle populations may have benefited from seasonal rains, which encourage growth of weeds which may act as hosts (Jayanth 1995). Sanitation of weeds would help reduce leaf beetle populations. Several weevils (Curculionidae) were observed, notably species of Cosmopolites, Compsus and Eustylus feeding on Cordyline, Dracaena and Pittosporium, which have not been previously reported from these plants. The adult stages of two genera of long horn beetles (Cerambycidae) were observed feeding on Anthericum and Ludovia, although it is not known whether either plant species would be suitable as reproductive hosts.

The most common dipteran species observed in our survey included lance flies (Lonchaeidae), followed by fungus gnats (Sciaridae), crane flies (Tipulidae), lauxaniids (Lauxaniidae), March flies (Bibionidae), and picture-winged flies (Ulidiidae). Many of these flies are detritivorous (saprophagous or mycophagous) in the larval stages and pollen feeding or non-feeding in the adult stages, and probably do not attack healthy undamaged plant tissue (McLachlan \& Ladle 2009). However, larvae of some species may attack damaged plant tissues or roots. For example, the lance fly Dasiops spp. has been reported to cause flower bud drop and fruit damage in sweet passion fruit, Passiflora ligularis Juss. (Umaña 2005). The picture winged fly Euxesta mazorca Steyskal, 1974, has been reported as damaging maize in Brazil 
Table II. Phytophagous and detritivorous genera and identified insect species collected among 34 farms growing foliage in Caldas, Quindío and Risaralda Departments, Colombia.

\begin{tabular}{|c|c|c|c|}
\hline Order & Family & Genus (species) & Collected from ${ }^{\mathrm{a}}$ \\
\hline \multirow[t]{4}{*}{ Coleoptera } & Cerambycidae & Peribaeum, Neoclytus balteatus LeConte, 1873 & 1,5 \\
\hline & Chrysomelidae & $\begin{array}{l}\text { Agroiconota, Cerotoma, Colaspis, Diabrotica fuscomaculata Jacoby, 1878, Epitrix parvula (Fabricius, 1801), } \\
\text { Nodonota, Omophoita, Systena }\end{array}$ & $1,2,3,5,6,7,8,9,11$ \\
\hline & Curculionidae & Compsus, Cosmopolites, Eustylus, Metamasius, Pantomorus, Sitophilus & $2,3,8$ \\
\hline & Scarabaeidae & Macraspis & 4 \\
\hline \multirow[t]{5}{*}{ Diptera } & Bibionidae & Bibio & 2,5 \\
\hline & Drosophilidae & Drosophila & 2,3 \\
\hline & Lonchaeidae & Dasiops & $2,5,9$ \\
\hline & Tephritidae & Rhagoletis & 9 \\
\hline & Ulidiidae & Chaetopsis & 2 \\
\hline \multirow[t]{16}{*}{ Hemiptera } & Aleyrodidae & Trialeurodes & 2 \\
\hline & Alydidae & Protenor & $1,2,3,5,9$ \\
\hline & Aphididae & Myzus persicae (Sulzer, 1776) & 8,9 \\
\hline & Berytidae & Jalysus & $2,3,8,9$ \\
\hline & Cicadellidae & Draeculacephala soluta Gibson, 1919, Empoasca kraemeri Ross \& Moore, 1957, Erythroneura, Tylozygus & $1,2,3,5,6,7,8,9$ \\
\hline & Coccidae & Ceroplastes, Saissetia & $2,6,7,8$ \\
\hline & Coreidae & $\begin{array}{l}\text { Althos obscurator (Fabricius, 1803), Chariesterus alternatus Distant, 1881, Hypselonotus atratus Distant, 1881, } \\
\text { H. interruptus Hahn, 1833, Sphictyrtus longirostris Distant, 1881, Zicca }\end{array}$ & $1,2,3,5,6,8,9,11$ \\
\hline & Delphacidae & Liburniella & 2 \\
\hline & Flatidae & Anormenis & $2,4,8$ \\
\hline & Fulgoridae & Cyrpoptus & $1,2,6,7,8$ \\
\hline & Lygaeidae & Neacoryphus bicrucis (Say, 1825) & $1,2,3$ \\
\hline & Membracidae & Archasia, Stictocephala & $1,2,3,4,6,8,9$ \\
\hline & Miridae & Collaria & $1,2,3,5,6,8$ \\
\hline & Ortheziidae & Orthezia praelonga Douglas, 1891 & 4,8 \\
\hline & Pentatomidae & Mayrinia, Mormidea, Proxys, Tibraca & $1,2,5,8,9$ \\
\hline & Tingidae & Gargaphia & 1 \\
\hline \multirow[t]{2}{*}{ Hymenoptera } & Apidae & Trigona & 4,6 \\
\hline & Formicidae & Atta cephalotes (Linnaeus, 1758), Acromyrmex, Paratrechina & $1,2,3,5,6,7,8$ \\
\hline \multirow[t]{4}{*}{ Lepidoptera } & Hesperiidae & Talides & 2 \\
\hline & Noctuidae & Spodoptera, Peridroma & $6,8,9,10$ \\
\hline & Nymphalidae & Actinote & 2 \\
\hline & Psychidae & Oiketicus & 2 \\
\hline \multirow[t]{2}{*}{ Orthoptera } & Eumastacidae & Homeomastax & 8 \\
\hline & Oecanthidae & Oecanthus & 1,7 \\
\hline
\end{tabular}

(Cruz et al. 2011). Good cultural practices to remove dead or dying plant tissues and preventing overwatering which promotes suitable habitat and growth of algae may help mitigate problems with many of these fly species. Some of these dipterans may be pollinators; Bibio species has been reported as a pollinator of Compositae (Morales 1988).

Whilst most Hymenoptera were considered beneficial, adult leaf cutting ants (Atta and Acromyrmex spp.) were observed harvesting Anthericum, Cordyline, Dracaena, Ludovia, Pandanus, Phormium and Pittosporum for their fungal colonies. Adult stingless Trigona bees were also observed damaging the tender stems of Eucalyptus and Phormium for nest building. Rasmussen et al. (2009) reported two species of Trigona damaging Jatropha curcas L., in Peru.

Other insects recovered in low numbers include several species of Lepidoptera and Orthoptera. Immature stages of noctuid moths (Spodoptera spp.) were collected from Phormium. Noctuid species are highly polyphagous, but often favor grasses including cereals and corn (Botton et al.
1998). Peridroma spp. were observed attacking stolons, roots and making small holes ( $3 \mathrm{~mm}$ diameter) in Ruscus leaves. The removal of weedy grasses, as well as use of biological insecticides such as Bacillus thuringiensis and releases of egg parasitoids is recommended to help control these pests (Garcia et al. 2002). An unidentified gelechiid leafminer moth was observed attacking Anthericum while larvae of a heliconid butterfly, Actinote sp., was observed feeding on Cordyline. Although larval stages may be damaging, we also note that the adult stages of butterflies or feeding moths may be beneficial by acting as pollinators. Several grasshoppers from 3 families (including several unidentified acridids) were collected in our survey and were observed feeding on Anthericum, Pandanus and Pittosporum.

Beneficial insects. Beneficial insects collected from tropical foliage included predators and parasitoids amongst five orders, 11 families, and 22 genera (Table III). Ladybeetles (Coleoptera, Coccinellidae) were amongst the most diverse and important predators of leafhoppers, scales, aphids, and 
Table III. Beneficial genera of insects collected among 34 farms growing tropical foliage in Caldas, Quindío and Risaralda Departments, Colombia.

\begin{tabular}{|c|c|c|c|}
\hline Order & Family & Genus (species) & Collected from $^{\mathrm{a}}$ \\
\hline \multirow[t]{4}{*}{ Coleoptera } & Carabidae & Pachyteles & $1,3,7,8$ \\
\hline & Coccinellidae & Cleothera, Cycloneda, Delphastus, Epilachna, Hyperaspis, Pentilia & $1,2,3,5,6,7,8,9$ \\
\hline & Lampyridae & Aspisoma & 2 \\
\hline & Lycidae & Lycinella parvula Gorham, 1884, Lygistopterus sanguineus (Linnaeus, 1758) & $1,2,3,5,8$ \\
\hline Diptera & Dolichopodidae & Pelastoneurus & 3,8 \\
\hline \multirow[t]{2}{*}{ Hemiptera } & Pentatomidae & Podisus & 1,8 , \\
\hline & Reduviidae & Elasmodema, Eupheno, Phymata, Zelus, Apiomerus & $1,2,8,9$ \\
\hline \multirow[t]{3}{*}{ Hymenoptera } & Apidae & Apis & 2 \\
\hline & Braconidae & Glyptapanteles & 3 \\
\hline & Formicidae & Ectatomma ruidum (Roger, 1860), Pseudomyrmex & $1,2,3,8,11$ \\
\hline Neuroptera & Chrysopidae & Chrysoperla & $2,3,8$ \\
\hline
\end{tabular}

other soft bodied insects, with 6 genera collected from all types of foliage plants except Eucalyptus. Also relatively frequently collected were adults from two genera of net-winged beetles (Lycidae) which are elongated, soft-bodied and often brightly colored. Lygistopterus sanguineus (Linnaeus, 1758) was observed feeding on leafhopper nymphs. Additional predatory beetles reported included a single genus of fireflies (Lampyridae), which are carnivorous in both adult and juvenile forms, and ground beetle (Carabidae).

Amongst other insect orders, immature stages of lacewings, Chrysoperla spp. and syrphid flies were observed feeding on scales and other pests. Two genera of ants (Ectatomma and Pseudomyrmex) were observed. While such ants are generalist insect predators, they are sometimes considered pests due to their habit of protecting aphids or other honeydew producing pests. It has been proposed that E. ruidum (Roger, 1860), a common ground-dwelling ant species in the Neotropics, could be managed as a biocontrol agent in some agroecosystems (Santamaría et al. 2009). Few parasitic Hymenoptera were found, possibly due to the toxic insecticides used by growers and lack of readily available hosts. Adults from a single genus from Ichneumonidae and Braconidae and a tachinid fly (caterpillar parasitoids) were observed. Several other specialized parasitoids were collected on occasion (Fig. 1). Beneficial Hemiptera included the predatory stink bug Podisus (Wiedenmann \& O'Neill 1992) and 5 genera of assassin bugs (Reduviidae) were observed feeding on caterpillars. On one occasion, an adult Apiomerus sp. was observed feeding on Trigona sp. A single genus Pelastoneurus of a long-legged fly (Dolichopodidae) was also observed feeding on other adult flies.

This is one of the first surveys of insects and pest management practices associated with commercial production of tropical foliage in Colombia. The relatively low abundance of many species of insects likely reflects the widespread use of broad spectrum insecticides. Nevertheless, we documented a wide range of herbivorous and beneficial insects in the region, which suggests some new insect plant associations. Since this was not an ecological study, we cannot conclude that all foliage plants from which insects were collected were reproductive hosts. Additional crops such as coffee, banana, passion fruit, tomato, maize, grass, Heliconia, avocado and Citrus grown in the surrounding areas could have served as the primary breeding sites for some adventive insects in foliage. Also, the sampling methods employed may have been biased towards the more conspicuous species, i.e. cryptic insects such as stem and root borers would be underrepresented in our survey. We note that most farmers used calendar applications of broad spectrum insecticides. This approach may be uneconomical and could compromise human and environmental health. Many farmers that we surveyed were interested in learning about integrated pest management to improve pest management practices and reduce the risk of insecticide resistance. A more selective insecticide program against key pests might allow greater function of the various beneficial insects that are present in this region. Further ecological studies of the insect fauna on tropical foliage plants are needed.

\section{ACKNOWLEDGEMENTS}

This research was supported by the Agricultural Sciences Faculty at the University of Caldas in Manizales, Colombia. We thank Dr. Manual Aristizábal for initiating this project and the Academic Vice Rectory for financial support. We are grateful to Felipe Peralta and Tropical Color and COLFLORAS for arranging contact with farmers and Gabriel Moura Mascarin for translation of the abstract. Constructive comments of two anonymous reviewers improved an earlier manuscript draft.

\section{REFERENCES}

Andrade-C. M.G., Garcia, G. A. \& Fernández, F. 1996. Insectos de Colombia: Estudios Escogidos. Santa Fe de Bogotá, Academia Colombiana de Ciencias Exactas, Fisicas y Naturales, 546 p.

ASOCOLFLORES 2008. Asociación Colombiana de Exportadores de Flores. Estadísticas 2007. Boletín Informativo 2008. Available at: http:/ /www.asocolflores.org (accessed 7 December 2012).

Botton, M., Carbonari, J.J., Garcia, M.S. \& Martins, J.F.S. 1998. Preferência alimentar e biologia de Spodoptera frugiperda (J.E. Smith) (Lepidoptera: Noctuidae) em arroz e capim-arroz. Anais da Sociedade Entomológica do Brasil 27: 207-212.

Cruz, I., da Silva, R.B., Figueiredo, M.D.C., Penteado-Dias, A.M., Del Sartol, M.C.L. \& Nuessly, G.S. 2011. Survey of ear flies (Diptera, 
Ulididae) in maize (Zea mays L.) and a new record of Euxesta mazorca Steyskal in Brazil. Revista Brasileira de Entomologia 55: 102-108. Descampe, A., Meskens, C., Pasteels, J., Windsor, D. \& Hance, T. 2008. Potential and realized feeding niches of neotropical hispine beetles (Chrysomelidae: Cassidinae, Cephaloleiini). Environmental Entomology 37: 224-229.

Diaz, J.A. 2006. Diagnóstico de la cadena productiva de heliconias y follajes en los departamentos del eje cafetero y Valle del Cauca (Colombia). Report for United Nations Conference for Trade and Development BioTrade Facilitation Program, 46 p.

Fernández, F. \& Sharkey, M.J. (eds) 2006. Introducción a los Hymenoptera de la Región Neotropical. Sociedad Colombiana de Entomología, 893 p.

Fernández, F., Andrade, M.G. \& Amat, G. 2004. El estudio de los insectos en Colombia y los retos de la entomología del nuevo siglo, p. 11-15. In: Fernández, F.., Andrade, M.G. \& Amat, G. (Eds.). Insectos de Colombia Vol. 3. Bogotá, Universidad Nacional de Colombia, Inst. Alexander Von Humboldt. 604 p.

Garcia, R.F., Mosquera, E.M.T., Vargas, S.C.A. \& Rojas, A.L. 2002. Control biologico, microbiologico y fisico de Spodoptera frugiperda (Lepidoptera: Noctuidae), plaga del maiz y otros cultivos en Colombia. Revista Colombiana de Entomologia 28: 53-60.

González, V.H., Ospina, M. \& Bennett, D.J. 2005. Abejas altoandinas de Colombia: Guía de campo. Bogotá, Instituto de Investigación de Recursos Biológicos Alexander von Humboldt, 80 p.

ICA. 2009. Instituto Colombiano Agropecuario. Incentivo Fitosanitario. Listado Definitivo de Productores Inscritos para Acceder al Incentivo Sanitario para Flores y Follajes 2009 (ISFF 2009). Ministerio de Agriculture y Desarrollo Rural. Available at: http://www.ica.gov.co (Accessed 7 December 2012)

Jayanth, K.P. 1995. Effect of soil moisture on population and adult emergence of Zygogramma bicolorata Pallister (Coleoptera: Chrysomelidae). Journal of Entomological Research 19: 183-185.

Kabaluk, J.T. \& Vernon, R.S. 2000. Effect of crop rotation on populations of Epitrix tuberis (Coleoptera: Chrysomelidae) in potato. Journal of Economic Entomology 93: 315-322.

Kornegay, J.L. \& Cardona, C. 1990. Development of an appropriate breeding scheme for tolerance to Empoasca kraemeri in common bean. Euphytica 47: 223-231.

Lawrence, J.F. 1991. Lycidae (Cantharoidea), p. 423-424. In Stehr, F.W. (ed.). Immature insects. Vol. 2. Dubuque, Iowa, Kendall/Hunt Publi. Co., 975 p.

Meyer, M.C., Costa, C.L. \& Santos, O.R. 1993. Transmission of four legume viruses by larvae of Cerotoma arcuata (Coleoptera; Chrysomelidae). Fitopatologia Brasileira 18: 97-101.

McLachlan, A.J. \& Ladle, R.J. 2009. The evolutionary ecology of detritus feeding in the larvae of freshwater Diptera. Biological Reviews 84: 133-141.

Morales, C.I. \& Medina, U.C. 2009. Insectos de la Orinoquía Colombiana: Evaluación a partir de la Colección Entomológica del Instituto Alexander von Humboldt (IAvH). Biota Colombina 10: 31-53.

Morales, S.G. 1988. Notas sobre taxonomía y clasificación de los insectos. Parte II. p. 114-157. Curso de Entomología General y Sistemática. Medellín, Universidad Nacional de Colombia, Facultad de Ciencias.

Rasmussen, C., Orihuela-Pasquel, P. \& Sánchez-Bocanegra, V. 2009. Abejas del género Trigona Jurine, 1807 (Hymenoptera: Apidae) como plaga del piñón blanco. Entomotropica 24: 31-34.

Santamaría, C., Armbrecht, I. \& Lachaud, J. 2009. Nest distribution and food preferences of Ectatomma ruidum (Hymenoptera: Formicidae) in shaded and open cattle pastures of Colombia. Sociobiology 53: 517-541.

Świerczewski, D. \& Stroiński, A. 2011. The first records of the Nearctic treehopper Stictocephala bisonia in Poland (Hemiptera: Cicadomorpha: Membracidae) with some comments on this potential pest. Polish Journal of Entomology 80: 13-22.

Umaña, M. 2005. Moscas de la fruta del genero Dasiops (Diptera: Lonchaeidae) asociadas a la curuba y recomendaciones generales para su manejo agroecologico en la vereda Cañon, municipio Sutamarchan - Boyaca. Revista Colombiana de Entomologia 31: 59-65.

Wiedenmann, R.N. \& O’Neill, R.J. 1992. Searching strategy of the predator Podisus maculiventris (Say) (Heteroptera: Pentatomidae). Environmental Entomology 21: 1-9.

Wolff, E.M. 2006. Insectos de Colombia. Guía básica de familias. Medellín, Universidad de Antioquia, 460 p.

Zumbado, M. 1999. Dípteros de Costa Rica. Heredia, INBio, 143 p.

Received 16 April 2013; accepted 15 May 2013

Associate Editor: Gustavo Graciolli 